\title{
Infection as a risk factor in the pathogenesis of primary biliary cirrhosis: Pros and cons
}

\author{
Teru Kumagi*, Masanori Abe, Yoshiou Ikeda and Yoichi Hiasa \\ Gastroenterology and Metabology, Ehime University, Graduate School of Medicine, Ehime, Japan
}

\begin{abstract}
Primary biliary cirrhosis (PBC) is a chronic and slowly progressive cholestatic liver disease of autoimmune etiology, characterized by injury of the intrahepatic bile ducts that may eventually lead to cirrhosis and liver failure. Evidence suggests cardinal roles for both environmental factors and genetic susceptibility. Nevertheless, the absolute etiology of PBC is unclear, despite recent well-designed case-control studies that reported environmental risk factors, including infectious agents, for PBC. Of the reported infectious agents, some of them are not reproducible and remain controversial. However, infection is no doubt one of the major risks among the environmental factors. This is supported by the fact that infectious agents in autoimmune diseases express antigens resulting in molecular mimicry and xenobiotics that play a role in breaking tolerance. Taken together, recent findings from genome wide assays as well as novel animal models may enable us to better understand the mechanism of pathogenesis responsible for this disease.
\end{abstract}

Keywords: Primary biliary cirrhosis, risk factors, infectious agents, xenobiotics

\section{Introduction}

Primary biliary cirrhosis (PBC) is an autoimmune liver disease that often affects middle-aged women. Anti-mitochondrial antibody (AMA), which is a hallmark of this disease, is present in approximately $90 \%$ of patients [1]. High association with other autoimmune diseases supports the concept of autoimmunity in PBC. Previous extensive evidence suggests a significant role for genetic susceptibility: family history [25], high concordance in monozygotic twins [6,7], HLA typing [8,9], SNP analysis [10-13] and, most strikingly, the results from recent genome wide assay [14-16]. Case-control studies support the idea that environmental factors may trigger the onset of the disease [17-25]. However, the environmental factors are less defined than genetic factors and the etiology of PBC is poorly understood.

*Corresponding author: Teru Kumagi, MD, Gastroenterology and Metabology, Ehime University, Graduate School of Medicine, Ehime, Japan; Shitsukawa, Toon, Ehime 791-0295, Japan. Tel.: +81 89960 5308; Fax: +81 89960 5310; E-mail: terukuma@m.ehimeu.ac.jp.
In this review, we will overview the risk factors for PBC. Furthermore, we will summarize the current knowledge of infectious agents, one of the major etiologies among environmental factors, and xenobiotics in the pathogenesis of PBC, and discuss the directions for future research.

\section{Overview of the risk factors in $\mathrm{PBC}$}

Until 2000, there were few published case-control studies of PBC that described some of the risk factors for the disease [17-20]. The first study, enrolling 38 patients with PBC by Baur $\mathrm{G}$ et al. in 1982, examined the high prevalence of miscarriage $(n=11,29 \%)$ in hospital in-patients as compared to their counterpart controls (with no liver disease, chronic-aggressive hepatitis and other forms of liver disease) [17]. Two studies investigated the association of urinary tract infection (UTI) with other liver disease by using controls: one by Burroughs A et al. $(n=89)$ [18] and the other by Floreani A et al. $(n=160)$ [19]. However, these studies did not take an age-match control into consideration during their analysis. Moreover, all of these studies recruited 
less than 160 patients with $\mathrm{PBC}$ in their cohort, which is far less than a recent case-control study that included over 2,500 patients [21]. Nevertheless, an observation of significant bacteriuria, for instance, found in patients with PBC [report by Burroughs A et al. showing higher prevalence in PBC (19\%) compared to other types of chronic liver disease $(7 \%)$ and rheumatoid arthritis $(8 \%)$ ] contributed and led to designing a study in order to further investigate the association of UTI. The only study using healthy age-matched controls and PBC patients ( $n=87$ ) compared the frequency of hysterectomy, dilatation and curettage: the indications in both instances being menorrhagia mainly caused by high estrogen states such as endometriosis [20]. Again, this finding encouraged the researchers to further examine involvement of reproductive factors in female patients with PBC.

Since 2000, there have been five large case-control studies [21-25], all from Western countries, which looked into risk factors for PBC [Tables 1, 2]. The Newcastle group conducted an exploratory, populationbased case-control study asking 123 patients to complete a questionnaire; 100 cases $(81 \%)$ responded [22]. Although they did not use multivariate analysis in their study, they found an unexpected association with past smoking history (ever smoked: OR 2.4, 95\% CI 1.44.1; smoked more than 20 years: OR 3.5, 95\% CI 1.9-6.3) and psoriasis (OR 4.6, 95\% CI 1.2-17.3) as risk factors, whereas eczema (OR $0.13,95 \%$ CI $0.02-$ 1.0) was found to be a "protective role". However, they failed to show an association to PBC in surgical procedures such as appendectomy and tonsillectomy, events in pregnancy, past infections including UTI, vaccinations, drinking alcohol or taking medications. The family history of PBC and other autoimmune diseases showed an associative tendency but this was found to be less than had been previously reported.

A decade later, the same group has recently expanded the study, recruiting patients from a geographically defined epidemiology study (epidemiological cases, $n=318$ ) and a survey of the National Patient Support Group (foundation cases, $n=2,258$ ) within Northeast England [21]. In the univariate analysis, they showed a significant association with smoking, hair dye use, previous history of UTI, psoriasis, shingles and previous autoimmune diseases as risk factors for PBC in both epidemiological cases and foundation cases as compared to the controls. For the first time, they have also shown previous obstetric cholestasis as a risk factor. Finally, they have strictly analyzed the aforementioned risk factors by using multivariate analysis and found a significant association to smoking, hair dye use and previous history of UTI in both epidemiological cases and foundation cases in comparison to controls, suggesting the strength of these three risk factors. Previous history of psoriasis, shingles, previous autoimmune diseases and previous obstetric cholestasis were significantly associated only in epidemiological cases or foundation cases but not in both. Additionally, they could not show the protective role of eczema in this study.

On the other hand, the first report from the United States in 2001 comparing PBC patients $(n=199)$ to their friends without PBC identified an association with other autoimmune diseases (OR 4.9, 95\% CI 2.4-10.2), smoking (OR 2.0, 95\% CI 1.1-3.8), tonsillectomies (OR 1.9, 95\% CI 1.0-3.4) and UTI in females only (OR 2.1, 95\% CI 1.1-4.1) [23]. These results of elevated ORs held true when compared between PBC patients and their siblings.

A nationwide controlled interview-based study from 23 tertiary referral centers for liver disease in the United States included 1032 patients [24]. Their data indicated that a first-degree relative with PBC (OR 10.8, 95\% CI 4.2-27.3), systemic lupus erythematosus (OR 2.2, 95\% CI 1.3-4.0), Sjogren syndrome (OR 5.8, 95\% CI 1.326.4), history of UTI (OR 1.5, 95\% CI 1.2-1.9), history of smoking (OR 1.6, 95\% CI 1.3-1.9), and use of hormonal replacement (OR 1.5, 95\% CI 1.3-1.9) were significantly associated with an increased risk of PBC. Interestingly, frequent use of nail polish was weakly associated with the risk of having PBC, indicating the involvement of cosmetics in the pathogenesis of PBC.

Another and most recent report from Europe but the first one from France confirmed some of the previously identified risk factors for PBC: family history of PBC (OR 6.8, 95\% CI 2.8-16.4), history of smoking (OR $3.1,95 \%$ CI 2.0-5.0) and UTI (OR 2.7, 95\% CI 2.03.7) [25].

Taken together with the results from the previous case-control studies, it is likely that environmental factors that include infectious agents through UTI (Escherichia coli as a representative bacterium), chemicals contained in cigarette smoke, cosmetics (nail polish and hair dye) and exogenous estrogens in female may induce PBC in genetically susceptible subjects.

\section{Infectious agents as an environmental factor in primary biliary cirrhosis}

Infectious agents such as Streptococcus and Campylobacter jejuni can induce disorders such as rheumat- 


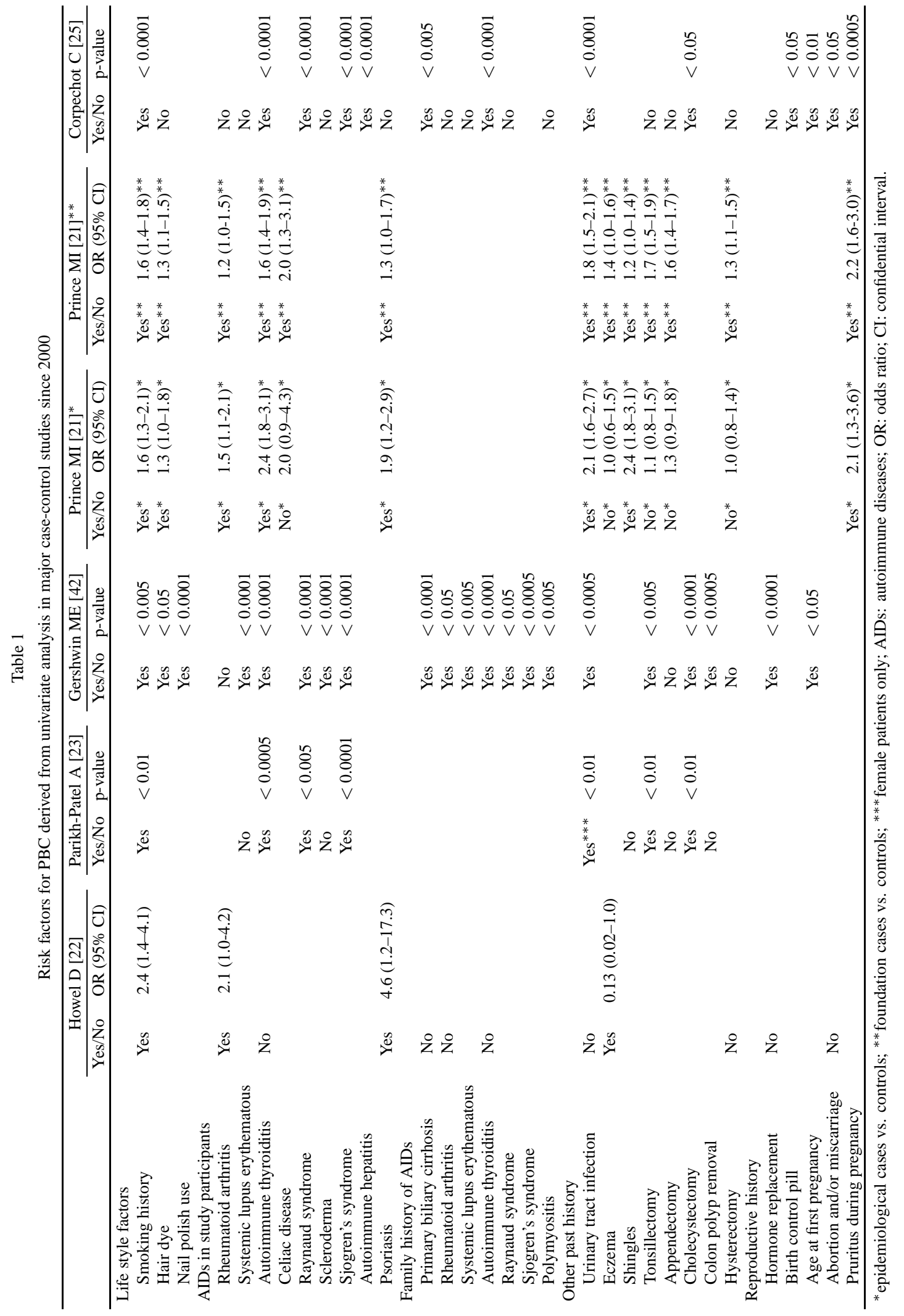




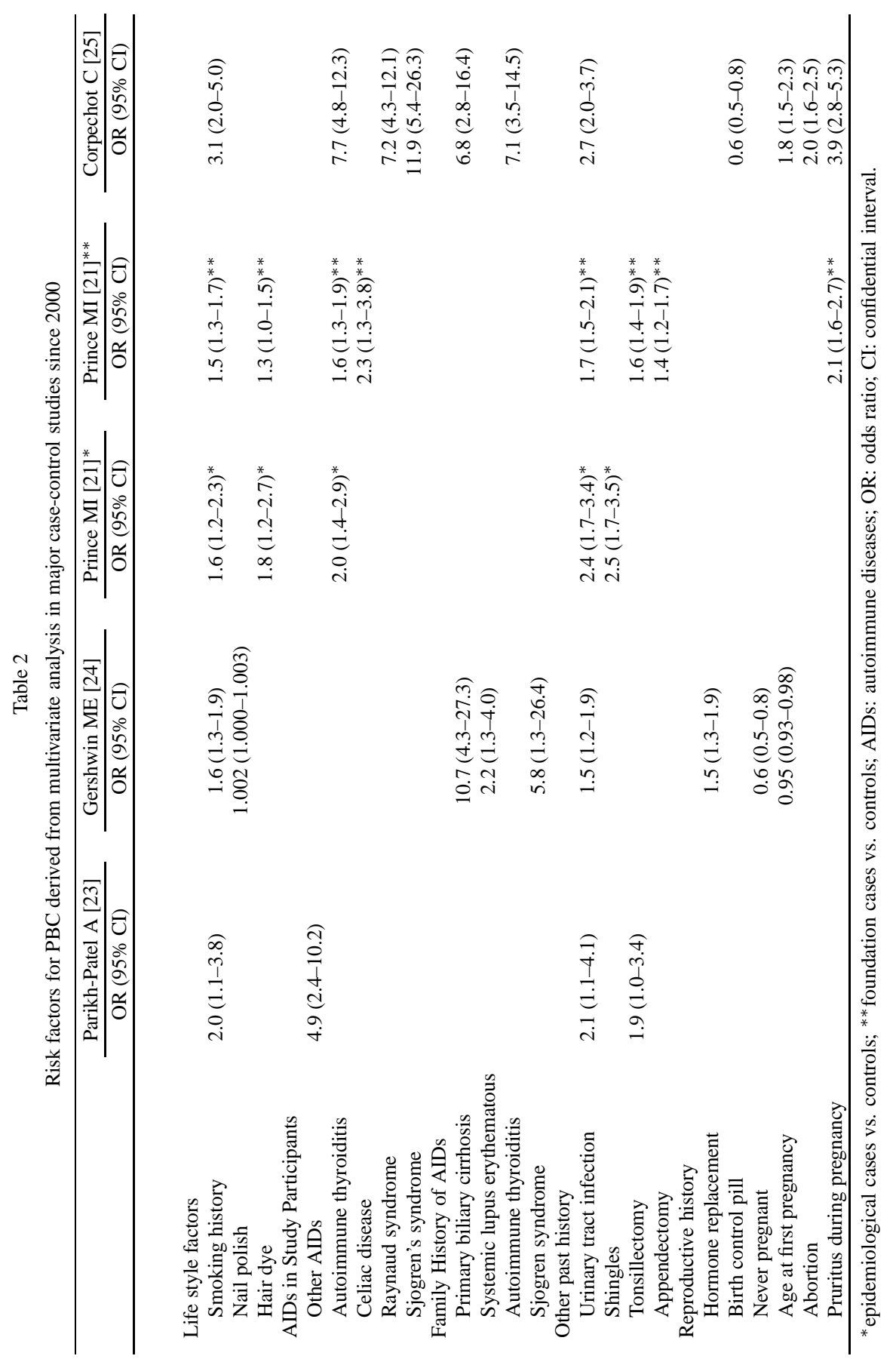


ic fever [26] and Guillain-Barré syndrome [27], respectively, in patients with autoimmune diseases. A pathogen under such circumstances might express antigens with epitopes that are structurally related to those of autoantigens, resulting in molecular mimicry, which might also play a causative role in the pathogenesis of PBC through human mitochondrial epitopes [28]. The ratio of seropositive AMA is $>90 \%$ in patients with $\mathrm{PBC}$ and the pyruvate dehydrogenase complexE2 (PDC)-E2 is a major human anti-mitochondrial autoantigen that is highly conserved among various species and has a high degree of similarity to the PDC sequences of Escherichia coli, Helicobacter pylori, cytomegalovirus and other microbes [28-30]. Some reports indicate that Novosphingobium aromaticivorans is also a potential initiator of PBC [31-33].

Although infectious agents can be associated with $\mathrm{PBC}$, and the degree of similarity between PDC-E2 and the PDC of infectious agents is high, AMA is not considered as a direct cause of biliary damage. Crossreactivity alone is not necessarily sufficient to evoke PBC. However, it could be a trigger by inducing the initial immune response to PDC-E2.

\subsection{Escherichia coli}

E. coli is a causative agent of PBC and a frequent cause of UTI, particularly among women, and predominantly new infection with recurrent UTI is a feature of PBC [18]. Studies of molecular mimicry and crossreactivity have shown that the affinity between human and E. coli PDC-E2 in patients with PBC is 100-fold higher than in controls [35]. The presence of bacterial products in mononuclear cells damages surrounding bile ducts [36]. AMA from patients with reactive $\mathrm{T}$ cells and prokaryotic antigens for several microbes, including $E$. coli and T cell clones derived from human PDC-E2, cross-reacted with peptides of $E$. coli PDC-E2 and E. coli OGDC-E2 [37]. These reactions would be caused by the sequences of PDC being highly conserved throughout their phylogeny [38].

\subsection{Novosphingobium aromaticivorans}

$N$. aromaticivorans is a Gram-negative bacterium of the Sphingomonodaceae family within the class of Alphaproteobacteria that is ubiquitous in the environment and closely associated with the pathogenesis of PBC [39]. Sera from patients with anti-PDC-E2positive $\mathrm{PBC}$ react at 100- to 1,000-fold higher titers against E. coli than N. aromaticivorans proteins [31], and such reactivity is evident during the early stages of PBC. The association between PBC and $N$. aromaticivorans infection has been confirmed in a mouse model [40], and it is capable of inducing autoreactive AMA and chronic T-cell-mediated autoimmunity against small bile ducts. Moreover, the specificity of serological findings has been confirmed in an independent cohort of patients and controls [34]. N. aromaticivorans could be a candidate for the induction of PBC.

\subsection{Helicobacter pylori}

Helicobacter pylori DNA has been detected in 33\% of patients with PBC [41]. Another report has described a positive correlation between the titers of anti-PDC and anti-H. pylori antibodies [42]. Molecular mimicry from H. pylori infection arising in patients with PBC [28] might induce an autoimmune response due to crossreactivity with bile ductular antigens. However, a later report did not identify an association between the seroprevalence of $H$. pylori infection and PBC [43]. Two other studies did not identify an increased prevalence of $H$. pylori DNA in liver tissues from patients with PBC $[44,45]$.

\subsection{Chlamydia pneumoniae}

Chlamydia pneumoniae is a cause of communityacquired pneumonia that might play a role in triggering PBC [46]. All of 39 patients with PBC had C. pneumoniae, but not $C$. trachomatis antigens. The RNA of C. pneumoniae has also been detected in liver tissues from patients with PBC. However, two other reports do not support the notion of an association between $C$. pneumoniae and PBC [47,48]. A Chinese study found that the seroprevalence of $C$. pneumoniae $\operatorname{IgG}$ does not differ between patients with PBC and those with post-hepatitis cirrhosis. However, C. pneumoniae IgM might contribute to the abnormally high concentrations of total IgM in patients with PBC.

\subsection{Other bacteria}

Studies of Spanish patients with PBC have revealed extensive, disease-specific cross-reactivity between the 65-kDa heat shock protein of Mycobacterium gordonae and PDC-E2 [49]. However, others have failed to confirm serum reactivity of Mycobacterium, or detect Mycobacterium DNA in patients with PBC [50,51].

Mycoplasma antigens have recently been proposed as a trigger of AMA in patients with PBC. Other 
cross-reactive responses involving mitochondrial and prokaryotic antigens have been reported, including Klebsiella pneumoniae, Proteus mirabilis, Staphylococcus aureus and Salmonella minnesota [38].

Long-term exposure of mouse models to bacteria triggers non-suppurative, destructive cholangitis associated with multifocal epithelial inflammation, suggesting that persistent and continuous bacterial infection is a trigger in the pathogenesis of PBC [52].

\subsection{Viruses}

Several viral infections might be associated with the pathogenesis of PBC. A retrovirus resembling the mouse mammary-tumor virus (MMTV) has been identified [53], and although pilot studies of single and combination antiretroviral therapy have indicated an association between MMTV and PBC [54], the findings were not reproducible [55]. The Epstein-Barr (EB) virus, which belongs to the herpes virus family, is a cause of infectious mononucleosis. Increased titers of $\mathrm{EB}$ virus antigen in the sera of patients with early $\mathrm{PBC}$ suggest that it could trigger PBC [56]. Similar peptide sequences between cytomegalovirus and human PDC indicate that this virus might also trigger PBC $[28,56]$.

\section{Xenobiotics and PBC}

The ability of infectious agents to induce autoimmune responses has been reported in experimental settings, and molecular mimicry is the most widely studied mechanism explaining these observations. However, titers of bacterial PDC-E2 were lower and appeared later in the disease than self (human) PDC [57]. These observations indicate that another etiological factor is necessary to break tolerance. In this regard, several lines of evidence support a role of xenobiotics in the development of PBC [58].

Xenobiotics are foreign chemicals that may either alter or combine with defined self proteins, inducing a change in the molecular structure of the naïve protein sufficient to induce an immune response in the host. Such an immune response may then result in the recognition of not only the modified or altered protein, but also the unmodified naïve antigen [59]. Chronic presence of both modified or naïve serves to perpetuate the immune response initiated by the xenobiotic-induced adducts and leads to autoimmunity [60]. Many xenobiotics can cause organ-specific autoimmune diseases.
It is well established that AMA and cellular responses in PBC are mainly directed to the lipoyl domain of PDC-E2. Lipoic acid is crucial to PDC-E2 recognition and lies exposed to the exterior part of the complex, thus constituting the ideal target for xenobiotic modification $[61,62]$. Xenobiotics may modify the lipoyl domain of PDC-E2 by creating neoantigens, possibly in concert with xenobiotic-modifying bacteria such as Novosphingobium aromaticivorans [31,32]. This hypothesis was supported by the observation that AMA from patients with $\mathrm{PBC}$ recognized a class of xenobiotic-modified PDC-E2 peptides, often with a higher affinity than with their naïve autoantigens [63]. In addition, immunization of animals with xenobiotics conjugated to bovine serum albumin caused serological and histopathological reaction similar to PBC [64-67]. The lipoylated bacterial proteins were further shown to have homology to human 2-oxo acid dehydrogenase enzymes [33]. These findings indicate that bacteria mimics containing lipoic acid residues might be modified by xenobiotics to form immunoreactive products. This modification might trigger a break in tolerance to autoantigens and the development of PBC.

\section{Conclusions and directions of future perspectives in the pathogenesis of $\mathrm{PBC}$}

Most of the epidemiological, experimental and clinical data concur to indicate the role of environmental factors, such as microorganisms and/or xenobiotics, in the induction of autoimmunity in PBC. Although a cause and effect relationship between infection and $\mathrm{PBC}$ has yet to be proven, there is evidence to suggest a role for bacterial agents, especially E. coli, in the development of PBC.

However, more data from epidemiological and clinical studies are necessary to directly link microbial infections with PBC. For example, most of the epidemiological studies of PBC have been conducted in the Europe and United States, and few data are available in many parts of the world. In addition, the role of infectious agents in the initiation of PBC has to be further probed, particularly by making a great effort to develop an experimental setting or animal model to ascertain exposure to specific environmental factors [6870]. Finally, $\mathrm{PBC}$ is a multifactor disease in that not only environmental factors are required but also genetic contributions. The informative genome studies, including a genome-wide association study, will help us to understand the pathogenesis of PBC. 


\section{References}

[1] T. Kumagi and E.J. Heathcote, Primary biliary cirrhosis, Orphanet J Rare Dis 3 (2008), 1.

[2] N. Bach and F. Schaffner, Familial primary biliary cirrhosis, $J$ Hepatol 20(6) (Jun 1994), 698-701.

[3] A.M. Brind and G.P. Bray, B.C. Portmann and R. Williams, Prevalence and pattern of familial disease in primary biliary cirrhosis, Gut 36(4) (Apr 1995), 615-617.

[4] D.E. Jones, F.E. Watt, J.V. Metcalf, M.F. Bassendine and O.F. James, Familial primary biliary cirrhosis reassessed: a geographically-based population study, J Hepatol 30(3) (Mar 1999), 402-407.

[5] L. Arbour, R. Rupps, L. Field, P. Ross, A. Erikson, H. Henderson, W. Hill and E. Yoshida, Characteristics of primary biliary cirrhosis in British Columbia's First Nations population, Can J Gastroenterol 19(5) (May 2005), 305-310.

[6] M.M. Kaplan, A.R. Rabson, Y.M. Lee, D.L. Williams and P.A. Montaperto, Discordant occurrence of primary biliary cirrhosis in monozygotic twins, $N$ Engl J Med 331(14) (Oct 1994), 951.

[7] C. Selmi, M.J. Mayo, N. Bach, H. Ishibashi, P. Invernizzi, R.G. Gish, S.C. Gordon, H.I. Wright, B. Zweiban, M. Podda and M.E. Gershwin, Primary biliary cirrhosis in monozygotic and dizygotic twins: genetics, epigenetics, and environment, Gastroenterology 127(2) (Aug 2004), 485-92.

[8] S. Onishi, T. Sakamaki, T. Maeda, S. Iwamura, A. Tomita, T. Saibara and Y. Yamamoto, DNA typing of HLA class II genes; DRB $1 * 0803$ increases the susceptibility of Japanese to primary biliary cirrhosis, J Hepatol 21(6) (Dec 1994), 10531060.

[9] P. Invernizzi, C. Selmi, F. Poli, S. Frison, A. Floreani, D. A1varo, P. Almasio, F. Rosina, M. Marzioni, L. Fabris, L. Muratori, L. Qi, M.F. Seldin, M.E. Gershwin and M. Podda, Italian PBC Genetic Study Group. Human leukocyte antigen polymorphisms in Italian primary biliary cirrhosis: a multicenter study of 664 patients and 1992 healthy controls, Hepatology 48(6) (Dec 2008), 1906-1912.

[10] K. Kikuchi, A. Tanaka, H. Miyakawa, Y. Kawashima, N. Kawaguchi, M. Matsushita and M.E. Gershwin, Eta1/osteopontin genetic polymorphism and primary biliary cirrhosis, Hepatol Res 26(2) (Jun 2003), 87-90.

[11] K. Kikuchi, A. Tanaka, M. Matsushita, E. Kitazawa, N. Hosoya, Y. Kawashima, C. Selmi, M.E. Gershwin and H. Miyakawa, Genetic polymorphisms of transforming growth factor beta-1 promoter and primary biliary cirrhosis in Japanese patients, Ann N Y Acad Sci 1110 (Sep 2007), 15-22.

[12] B.D. Juran, E.J. Atkinson, E.M. Schlicht, B.L. Fridley, G.M Petersen and K.N. Lazaridis, Interacting alleles of the coinhibitory immunoreceptor genes cytotoxic T-lymphocyte antigen 4 and programmed cell-death 1 influence risk and features of primary biliary cirrhosis, Hepatology 47(2) (Feb 2008), $563-570$.

[13] S. Joshita, T. Umemura, K. Yoshizawa, Y. Katsuyama, E. Tanaka and M. Ota, Shinshu PBC Study Group. A2BP1 as a novel susceptible gene for primary biliary cirrhosis in Japanese patients, Hum Immunol 71(5) (May 2010), 520-524.

[14] G.M. Hirschfield, X. Liu, C. Xu, Y. Lu, G. Xie, Y. Lu, X. Gu, E.J. Walker, K. Jing, B.D. Juran, A.L. Mason, R.P. Myers, K.M. Peltekian, C.N. Ghent, C. Coltescu, E.J. Atkinson, E.J. Heathcote, K.N. Lazaridis, C.I. Amos and K.A. Siminovitch, Primary biliary cirrhosis associated with HLA, IL12A, and IL12RB2 variants, N Engl J Med 360(24) (Jun 2009), 25442555 .
[15] G.M. Hirschfield, X. Liu, Y. Han, I.P. Gorlov, Y. Lu, C. Xu, Y. Lu, W. Chen, B.D. Juran, C. Coltescu, A.L. Mason, P. Milkiewicz, R.P. Myers, J.A. Odin, V.A. Luketic, D. Speiciene, C. Vincent, C. Levy, P.K. Gregersen, J. Zhang, E.J. Heathcote, K.N. Lazaridis, C.I. Amos and K.A. Siminovitch, Variants at IRF5-TNPO3, 17q12-21 and MMEL1 are associated with primary biliary cirrhosis, Nat Genet $\mathbf{4 2}(8)$ (Aug 2010), 655-657 [Epub 2010 Jul 18].

[16] X. Liu, P. Invernizzi, Y. Lu, R. Kosoy, Y. Lu, I. Bianchi, M. Podda, C. Xu, G. Xie, F. Macciardi, C. Selmi, S. Lupoli, R. Shigeta, M. Ransom, A. Lleo, A.T. Lee, A.L. Mason, R.P. Myers, K.M. Peltekian, C.N. Ghent, F. Bernuzzi, M. Zuin, F. Rosina, E. Borghesio, A. Floreani, R. Lazzari, G. Niro, A. Andriulli, L. Muratori, P. Muratori, P.L. Almasio, P. Andreone, M. Margotti, M. Brunetto, B. Coco, D. Alvaro, M.C. Bragazzi, F. Marra, A. Pisano, C. Rigamonti, M. Colombo, M. Marzioni, A. Benedetti, L. Fabris, M. Strazzabosco, P. Portincasa, V.O. Palmieri, C. Tiribelli, L. Croce, S. Bruno, S. Rossi, M. Vinci, C. Prisco, A. Mattalia, P. Toniutto, A. Picciotto, A. Galli, C. Ferrari, S. Colombo, G. Casella, L. Morini, N. Caporaso, A. Colli, G. Spinzi, R. Montanari, P.K. Gregersen, E.J. Heathcote, G.M. Hirschfield, K.A. Siminovitch, C.I. Amos, M.E. Gershwin and M.F. Seldin, Genome-wide meta-analyses identify three loci associated with primary biliary cirrhosis, Nat Genet 42(8) (Aug 2010), 658-660 [Epub 2010 Jul 18].

[17] G. Baur, G. Schwalbach and W. Tittor, New aspects of the pathogenesis of primary biliary cirrhosis, a study of 42 patients, Dtsch Med Wochenschr 107(10) (Mar 1982), 378-382.

[18] A.K. Burroughs, I.J. Rosenstein, O. Epstein, J.M. HamiltonMiller, W. Brumfitt and S. Sherlock, Bacteriuria and primary biliary cirrhosis, Gut 25(2) (Feb 1984), 133-137.

[19] A. Floreani, M.F. Bassendine, H. Mitchison, R. Freeman and O.F. James, No specific association between primary biliary cirrhosis and bacteriuria? J Hepatol 8(2) (Mar 1989), 201207.

[20] A.J. Stellon and R. Williams, Increased incidence of menstrual abnormalities and hysterectomy preceding primary biliary cirrhosis, BMJ 293(6542) (Aug 1986), 297-298.

[21] M.I. Prince, S.J. Ducker and O.F. James, Case-control studies of risk factors for primary biliary cirrhosis in two United Kingdom populations, Gut 59(4) (Apr 2010), 508-512.

[22] D. Howel, C.M. Fischbacher, R.S. Bhopal, J. Gray, J.V. Metcalf and O.F. James, An exploratory population-based casecontrol study of primary biliary cirrhosis, Hepatology 31(5) (May 2000), 1055-1060.

[23] A. Parikh-Patel, E.B. Gold, H. Worman, K.E. Krivy and M.E. Gershwin Risk factors for primary biliary cirrhosis in a cohort of patients from the united states, Hepatology 33 (2001), 1621.

[24] M.E. Gershwin, C. Selmi, H.J. Worman, E.B. Gold, M. Watnik, J. Utts, K.D. Lindor, M.M. Kaplan and J.M. Vierling, USA PBC Epidemiology Group. Risk factors and comorbidities in primary biliary cirrhosis: a controlled interview-based study of 1032 patients, Hepatology 42 (2005), 1194-1202.

[25] C. Corpechot, Y. Chrétien, O. Chazouillères and R. Poupon, Demographic, lifestyle, medical and familial factors associated with primary biliary cirrhosis, J Hepatol 53(1) (Jul 2010), 162-169.

[26] M.W. Cunningham, S.M. Antone, M. Smart, R. Liu and S. Kosanke, Molecular analysis of human cardiac myosin-crossreactive B- and T-cell epitopes of the group A streptococcal M5 protein, Infect Immun 65 (1997), 3913-3923.

[27] J.H. Rees, S.E. Soudain, N.A. Gregson and R.A. Hughes, Campylobacter jejuni infection and Guillain-Barré syndrome, 
N Engl J Med 333 (1995), 1374-1379.

[28] D.P. Bogdanos, H. Baum, A. Grasso, M. Okamoto, P. Butler, Y. Ma, E. Rigopoulou, P. Montalto, E.T. Davies, A.K. Burroughs and D. Vergani, Microbial mimics are major targets of crossreactivity with human pyruvate dehydrogenase in primary biliary cirrhosis, J Hepatol 40 (2004), 31-39.

[29] N. Agmon-Levin, B.S. Katz and Y. Shoenfeld, Infection and primary biliary cirrhosis, Isr Med Assoc J11 (2009), 112-115.

[30] D.P. Bogdanos and D. Vergani, Bacteria and primary biliary cirrhosis, Clin Rev Allergy Immunol 36 (2009), 30-39.

[31] C. Selmi, D.L. Balkwill, P. Invernizzi, A.A. Ansari, R.L. Coppel, M. Podda, P.S. Leung, T.P. Kenny, J. Van De Water, M.H. Nantz, M.J. Kurth and M.E. Gershwin, Patients with primary biliary cirrhosis react against a ubiquitous xenobioticmetabolizing bacterium, Hepatology 38 (2003), 1250-1257.

[32] M.M. Kaplan Novosphingobium aromaticivorans: a potential initiator of primary biliary cirrhosis, Am J Gastroenterol 99 (2004), 2147-2149.

[33] K.A. Padgett, C. Selmi, T.P. Kenny, P.S. Leung, D.L. Balkwill, A.A. Ansari, R.L. Coppel and M.E. Gershwin, Phylogenetic and immunological definition of four lipoylated proteins from Novosphingobium aromaticivorans, implications for primary biliary cirrhosis, J Autoimmun 24 (2005), 209-219.

[34] S. Olafsson, H. Gudjonsson, C. Selmi, K. Amano, P. Invernizzi, M. Podda and M.E. Gershwin, Antimitochondrial antibodies and reactivity to N. aromaticivorans proteins in Icelandic patients with primary biliary cirrhosis and their relatives, Am J Gastroenterol 99 (2004), 2143-2146.

[35] H. Miyakawa, A. Tanaka, C. Selmi, N. Hosoya, N. Mataki, K. Kikuchi, T. Kato, J. Arai, T. Goto and M.E. Gershwin, Serum reactivity against bacterial pyruvate dehydrogenase: increasing the specificity of anti-mitochondrial antibodies for the diagnosis of primary biliary cirrhosis, Clin Dev Immunol 13 (2006), 289-294.

[36] K. Tsuneyama, K. Harada, N. Kono, K. Hiramatsu, Y. Zen, Y. Sudo, M.E. Gershwin, M. Ikemoto, H. Arai and Y. Nakanuma, Scavenger cells with gram-positive bacterial lipoteichoic acid infiltrate around the damaged interlobular bile ducts of primary biliary cirrhosis, J Hepatol 35 (2001), 156-163.

[37] S. Shimoda, M. Nakamura, H. Shigematsu, H. Tanimoto, T. Gushima, M.E. Gershwin and H. Ishibashi, Mimicry peptides of human PDC-E2 163-176 peptide, the immunodominant Tcell epitope of primary biliary cirrhosis, Hepatology 31 (2000), 1212-1216.

[38] J. Van de Water, H. Ishibashi, R.L. Coppel and M.E. Gershwin, Molecular mimicry and primary biliary cirrhosis: premises not promises, Hepatology 33 (2001), 771-775.

[39] J.P. Mohammed and J. Mattner, Autoimmune disease triggered by infection with alphaproteobacteria, Expert Rev Clin Immunol 5 (2009), 369-379.

[40] J. Mattner, P.B. Savage, P. Leung, S.S. Oertelt, V. Wang, O. Trivedi, S.T. Scanlon, K. Pendem, L. Teyton, J. Hart, W.M. Ridgway, L.S. Wicker, M.E. Gershwin and A. Bendelac, Liver autoimmunity triggered by microbial activation of natural killer T cells, Cell Host Microbe 3 (2008), 304-315.

[41] H.O. Nilsson, J. Taneera, M. Castedal, E. Glatz, R. Olsson and T. Wadström, Identification of Helicobacter pylori and other Helicobacter species by PCR, hybridization, and partial DNA sequencing in human liver samples from patients with primary sclerosing cholangitis or primary biliary cirrhosis, $J$ Clin Microbiol 38 (2000), 1072-1076.

[42] K. Dohmen, H. Shigematsu, Y. Miyamoto, F. Yamasaki, K. Irie and $\mathrm{H}$. Ishibashi, Atrophic corpus gastritis and Helicobacter pylori infection in primary biliary cirrhosis, Dig Dis Sci $\mathbf{4 7}$ (2002), 162-169.

[43] M. Durazzo, F. Rosina, A. Premoli, E. Morello, S. Fagoonee, R. Innarella, E. Solerio, R. Pellicano and M. Rizzetto, Lack of association between seroprevalence of Helicobacter pylori infection and primary biliary cirrhosis, World J Gastroenterol 10 (2004), 3179-3181.

[44] A. Tanaka, T.P. Prindiville, R. Gish, J.V. Solnick, R.L. Coppel, E.B. Keeffe, A. Ansari and M.E. Gershwin, Are infectious agents involved in primary biliary cirrhosis? A PCR approach, J Hepatol 31 (1999), 664-671.

[45] S.Y. Boomkens, S. de Rave, R.G. Pot, H.F. Egberink, L.C. Penning, J. Rothuizen, P.E. Zondervan and J.G. Kusters, The role of Helicobacter spp. in the pathogenesis of primary biliary cirrhosis and primary sclerosing cholangitis, FEMS Immunol Med Microbiol 44 (2005), 221-225.

[46] A.S. Abdulkarim, L.M. Petrovic, W.R. Kim, P. Angulo, R.V. Lloyd and K.D. Lindor, Primary biliary cirrhosis: an infectious disease caused by Chlamydia pneumoniae? J Hepatol 40 (2004), 380-384

[47] D. Taylor-Robinson, A.W. Sharif, N.S. Dhanjal and S.D. Taylor-Robinson, Chlamydia pneumoniae infection is an unlikely cause of primary biliary cirrhosis, J Hepatol $\mathbf{4 2}$ (2005), 779-780.

[48] H.Y. Liu, A.M. Deng, J. Zhang, Y. Zhou, D.K. Yao, X.Q. Tu, L.Y. Fan and R.Q. Zhong, Correlation of Chlamydia pneumoniae infection with primary biliary cirrhosis, World J Gastroenterol 41 (2005), 4108-4110.

[49] L. Vilagut, A. Parés, O. Viñas, J. Vila, M.T. Jiménez de Anta and J. Rodés, Antibodies to mycobacterial $65-\mathrm{kD}$ heat shock protein cross-react with the main mitochondrial antigens in patients with primary biliary cirrhosis, Eur J Clin Invest 27 (1997), 667-672.

[50] D.P. Bogdanos, A. Pares, H. Baum, L. Caballeria, E.I. Rigopoulou, Y. Ma, A.K. Burroughs, J. Rodes and D. Vergani, Disease-specific cross-reactivity between mimicking peptides of heat shock protein of Mycobacterium gordonae and dominant epitope of E2 subunit of pyruvate dehydrogenase is common in Spanish but not British patients with primary biliary cirrhosis, J Autoimmun 22 (2004), 353-362.

[51] J. O'Donohue, B. McFarlane, A. Bomford, M. Yates and R. Williams, Antibodies to atypical mycobacteria in primary biliary cirrhosis, J Hepatol 21 (1994), 887-889.

[52] I. Haruta, K. Kikuchi, E. Hashimoto, M. Nakamura, H. Miyakawa, K. Hirota, N. Shibata, H. Kato, Y. Arimura, Y. Kato, T. Uchiyama, H. Nagamune, M. Kobayashi, Y. Miyake, K. Shiratori and J. Yagi, Long-term bacterial exposure can trigger nonsuppurative destructive cholangitis associated with multifocal epithelial inflammation, Lab Invest 90 (2010), 577-588.

[53] L. Xu, M. Sakalian, Z. Shen, G. Loss, J. Neuberger and A. Mason, Cloning the human betaretrovirus proviral genome from patients with primary biliary cirrhosis, Hepatology 39 (2004), 151-156.

[54] A.L. Mason, G.H. Farr, L. Xu, S.G. Hubscher and J.M. Neuberger, Pilot studies of single and combination antiretroviral therapy in patients with primary biliary cirrhosis, Am J Gastroenterol 99(12) (2004), 2348-2355.

[55] C. Selmi, S.R. Ross, A.A. Ansari, P. Invernizzi, M. Podda, R.L. Coppel and M.E. Gershwin, Lack of immunological or molecular evidence for a role of mouse mammary tumor retrovirus in primary biliary cirrhosis, Gastroenterology 127 (2004), 493-501.

[56] O. Barzilai, Y. Sherer, M. Ram, D. Izhaky, J.M. Anaya and Y. Shoenfeld, Epstein-Barr virus and cytomegalovirus in au- 
toimmune diseases: are they truly notorious? A preliminary report, Ann N Y Acad Sci 1108 (2007), 567-577.

[57] S.P. Fussey, J.G. Lindsay, C. Fuller, R.N. Perham, S. Dale, O.F. James, M.F. Bassendine and S.J. Yeaman, Autoantibodies in primary biliary cirrhosis: analysis of reactivity against eukaryotic and prokaryotic 2-oxo acid dehydrogenase complexes, Hepatology 13(3) (1991), 467-474.

[58] C. Selmi and M.E. Gershwin, The role of environmental factors in primary biliary cirrhosis, Trends Immunol 30(8) (2009), 415-420.

[59] N.R. Rose, Viral damage or 'molecular mimicry'-placing the blame in myocarditis, Nat Med 6(6) (2000), 631-632.

[60] C. Selmi, C.A. Cocchi, M. Zuin and M.E. Gershwin, The chemical pathway to primary biliary cirrhosis, Clin Rev Allergy Immunol 36(1) (2009), 23-29.

[61] S.F. Bruggraber, P.S. Leung, K. Amano, C. Quan, M.J. Kurth, M.H. Nantz, G.D. Benson, J. Van de Water, V. Luketic, T.E. Roche, A.A. Ansari, R.L. Coppel and M.E. Gershwin, Autoreactivity to lipoate and a conjugated form of lipoate in primary biliary cirrhosis, Gastroenterology 125(6) (2003), 1705-1713.

[62] H.R. Walden, J.A. Kirby, S.J. Yeaman, J. Gray, D.E. Jones and J.M. Palmer, Xenobiotic incorporation into pyruvate dehydrogenase complex can occur via the exogenous lipoylation pathway, Hepatology 48(6) (2008), 1874-1884.

[63] S.A. Long, C. Quan, J. Van de Water, M.H. Nantz, M.J. Kurth, D. Barsky, M.E. Colvin, K.S. Lam, R.L. Coppel, A. Ansari and M.E. Gershwin, Immunoreactivity of organic mimeotopes of the E2 component of pyruvate dehydrogenase: connecting xenobiotics with primary biliary cirrhosis, J Immunol 167(5) (2001), 2956-2963.

[64] P.S. Leung, C. Quan, O. Park, J. Van de Water, M.J. Kurth, M.H. Nantz, A.A. Ansari, R.L. Coppel, K.S. Lam and M.E. Gershwin, Immunization with a xenobiotic 6-bromohexanoate bovine serum albumin conjugate induces antimitochondrial antibodies, J Immunol 170(10) (2003), 5326-5332.

[65] K. Amano, P.S. Leung, R. Rieger, C. Quan, X. Wang, J. Marik,
Y.F. Suen, M.J. Kurth, M.H. Nantz, A.A. Ansari, K.S. Lam, M. Zeniya, E. Matsuura, R.L. Coppel and M.E. Gershwin, Chemical xenobiotics and mitochondrial autoantigens in primary biliary cirrhosis: identification of antibodies against a common environmental, cosmetic, and food additive, 2-octynoic acid, J Immunol 174(9) (2005), 5874-5883.

[66] P.S. Leung, O. Park, K. Tsuneyama, M.J. Kurth, K.S. Lam, A.A. Ansari, R.L. Coppel and M.E. Gershwin, Induction of primary biliary cirrhosis in guinea pigs following chemical xenobiotic immunization, J Immunol 179(4) (2007), 26512657.

[67] K. Wakabayashi, Z.X. Lian, P.S. Leung, Y. Moritoki, K. Tsuneyama, M.J. Kurth, K.S. Lam, K. Yoshida, G.X. Yang, T. Hibi, A.A. Ansari, W.M. Ridgway, R.L. Coppel, I.R. Mackay and M.E. Gershwin, Loss of tolerance in C57BL/6 mice to the autoantigen E2 subunit of pyruvate dehydrogenase by a xenobiotic with ensuing biliary ductular disease, Hepatology 48(2) (2008), 531-540.

[68] J. Irie, Y. Wu, L.S. Wicker, D. Rainbow, M.A. Nalesnik, R. Hirsch, L.B. Peterson, P.S. Leung, C. Cheng, I.R. Mackay, M.E. Gershwin and W.M. Ridgway, NOD.c3c4 congenic mice develop autoimmune biliary disease that serologically and pathogenetically models human primary biliary cirrhosis, J Exp Med 203(5) (2006), 1209-1219.

[69] K. Wakabayashi, Z.X. Lian, Y. Moritoki, R.Y. Lan, K. Tsuneyama, Y.H. Chuang, G.X. Yang, W. Ridgway, Y. Ueno, A.A. Ansari, R.L. Coppel, I.R. Mackay and M.E. Gershwin, IL-2 receptor alpha $(-/-)$ mice and the development of primary biliary cirrhosis, Hepatology 44(5) (Nov 2006), 12401249.

[70] S. Oertelt, Z.X. Lian, C.M. Cheng, Y.H. Chuang, K.A. Padgett, X.S. He, W.M. Ridgway, A.A. Ansari, R.L. Coppel, M.O. Li, R.A. Flavell, M. Kronenberg, I.R. Mackay and M.E. Gershwin, Anti-mitochondrial antibodies and primary biliary cirrhosis in TGF-beta receptor II dominant-negative mice, $J$ Immunol 177(3) (Aug 2006), 1655-1660. 


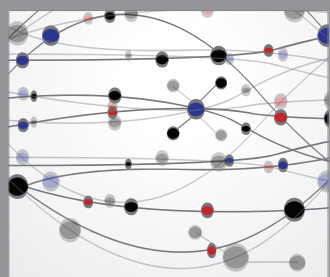

The Scientific World Journal
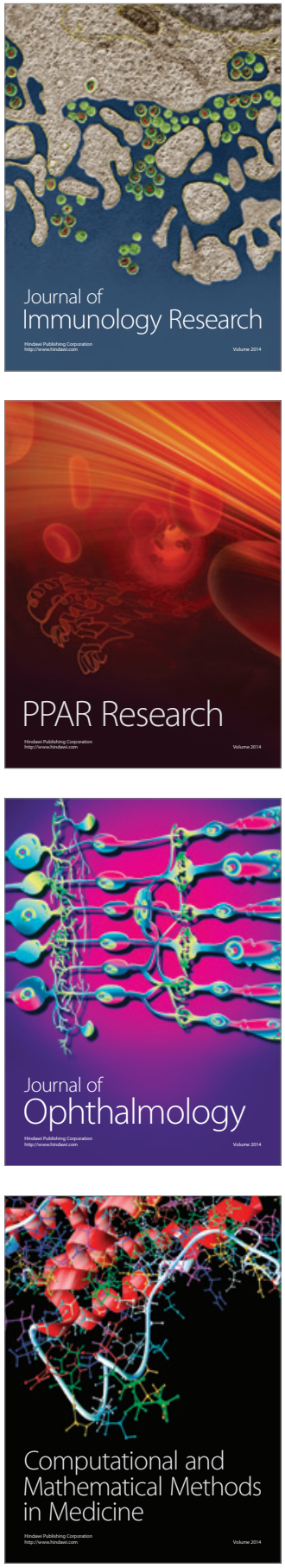

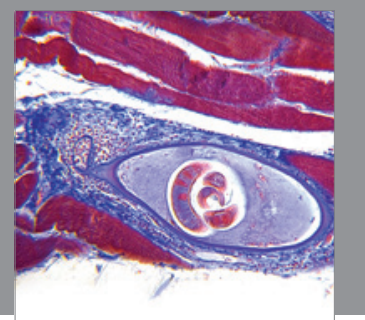

Gastroenterology

Research and Practice
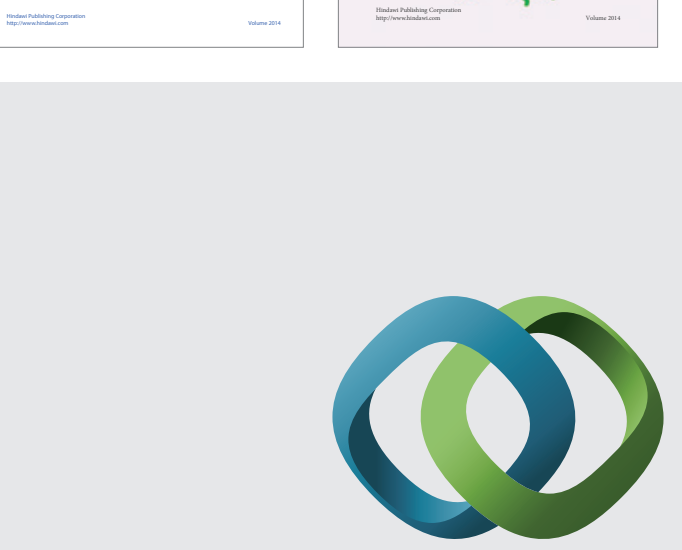

\section{Hindawi}

Submit your manuscripts at

http://www.hindawi.com
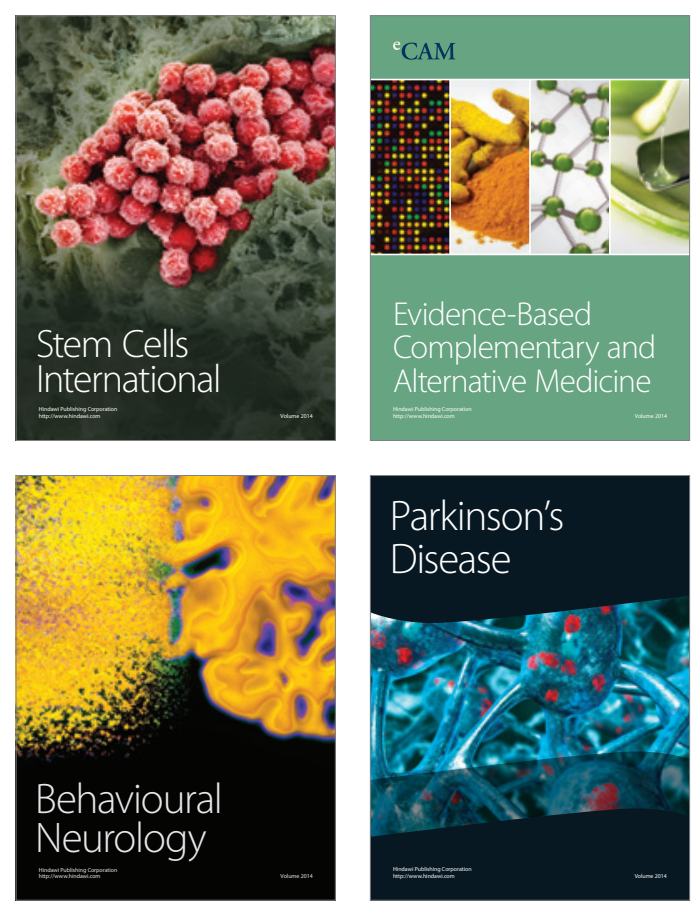

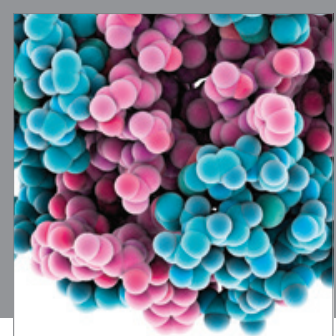

Journal of
Diabetes Research

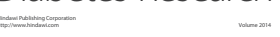

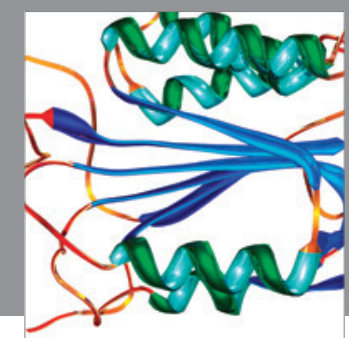

Disease Markers
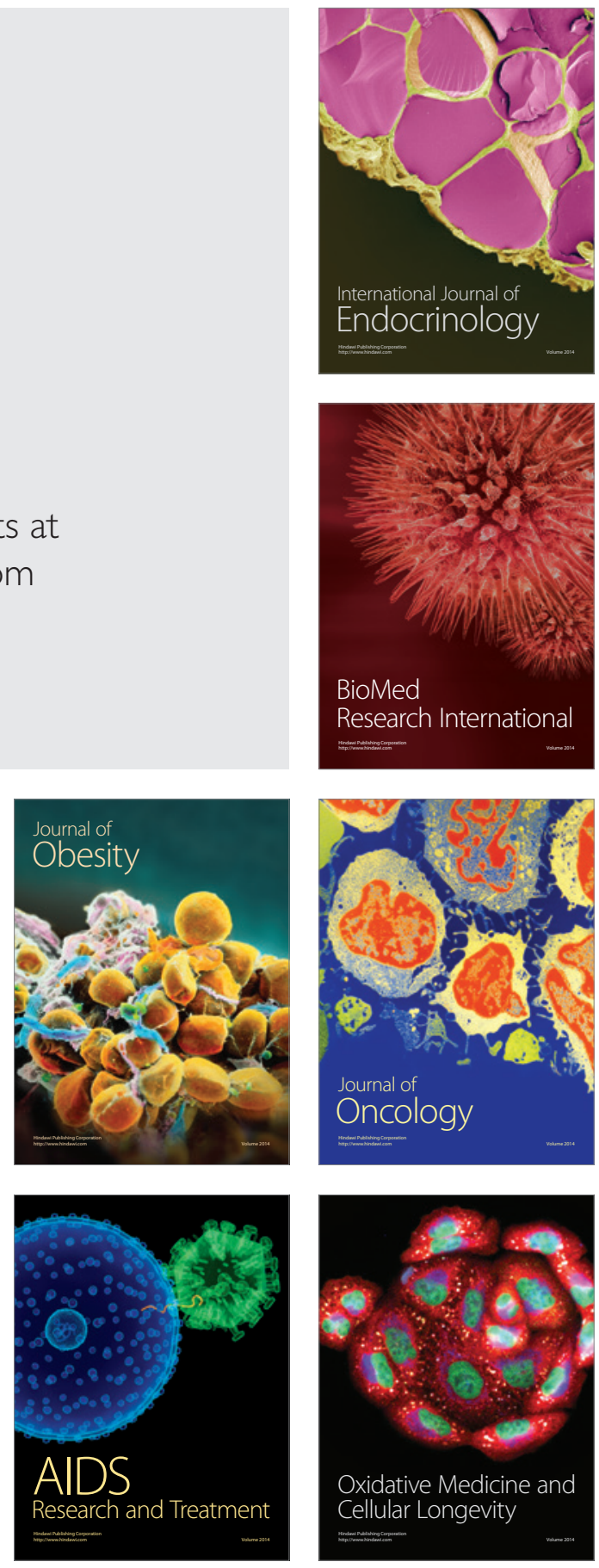